\title{
Relationship Marketing and Information Technology's Impact on Customer Satisfaction and Commitment
}

\author{
Kamal Abubakar Abraham Sleiman ${ }^{1,2}$, Xiangyu Cai ${ }^{*}{ }^{*}$, Juanli Lan' ${ }^{1}$, Hongzhen Lei ${ }^{1}$, Ru Liu $^{1}$ \\ ${ }^{1}$ International School of Business, Shaanxi Normal University, Xi'an, China \\ ${ }^{2}$ Faculty of Economics \& Management Science, Al-Zaiem Al-Azhari University, Khartoum North, Sudan \\ ${ }^{3}$ Xi'an University of Finance and Economics, Xi'an, China \\ Email: ${ }^{\star} 408279976 @ q q . c o m$
}

How to cite this paper: Sleiman, K. A. A., Cai, X. Y., Lan, J. L., Lei, H. Z., \& Liu, R. (2021). Relationship Marketing and Information Technology's Impact on Customer Satisfaction and Commitment. Open Journal of Business and Management, 9, 10301049.

https://doi.org/10.4236/ojbm.2021.93055

Received: March 4, 2021

Accepted: April 13, 2021

Published: April 16, 2021

Copyright $\odot 2021$ by author(s) and Scientific Research Publishing Inc. This work is licensed under the Creative Commons Attribution International License (CC BY 4.0).

http://creativecommons.org/licenses/by/4.0/

\begin{abstract}
The rapid growth of the technology industry has changed the condition of relationship marketing. The business has simultaneously become more comfortable and more complicated. It is easier because one can send and receive business information in the click of a button, it is complicated because the new technologies bring new demand and challenges to the companies. The use of self-service technology is widespread in China. The purpose of this paper is to show the impact of information technology on relationship marketing and the factors that lead to customer satisfaction and commitment to SSTs usage. SPSS was used for the study. The finding of this study shows that trust is a significant factor for achieving customer satisfaction and commitment, followed by perceived convenience. Customer satisfaction has the highest relationship with customer commitment. This study may help the bank administration to improve the (ATM) self-service technology in a way that will bring more satisfaction to the customer, which will result in commitment.
\end{abstract}

\section{Keywords}

Relationship Marketing, Information Technology, Self-Service Technology, Trust

\section{Introduction}

It's essential to consider relationship marketing for a better understanding of IT in a business relationship. The energy crisis of 1970, the emergence of service marketing, and supplier partner (Sheth, 2002) were responsible for the develop- 
ment of relationship marketing in the late 1980s and early 1990s as a new domain. This new approach had shifted the business' focus from one of acquiring new customers to one of retaining current customers (Berry, 1995). Previously, the marketing philosophy was focused on the sales process. The most expensive factor in marketing is attracting new customers. The cost of acquiring new customers is estimated to be five times the cost of retaining current customers (Kotler et al., 2013). Therefore, businesses had tried various ways of attracting customers but had little success to keep them. Relationship marketing focuses on customer loyalty and establishing long-term customer relationships, with a dramatic change in business environment relationship marketing, focuses on technology to build long-term relationships with customers.

The advent of technology shifted marketing from relationship marketing to technology interactions marketing (Klier et al., 2016). This new technology influenced the relationship between firms and customers; that is what makes the firms interact to be based on technology instead of the old previous way (Collier \& Sherrell, 2010). The new technology had changed the way of delivering services between companies and customers. Companies begin to use self-service technology instead of delivering service face to face (Robertson et al., 2016a). Self-service technology allows the customer to utilize various benefits and services without the direct involvement of employees (Nijssen, Schepers, \& Belanche, 2016). The perceived of SSTs has become more popular due to service delivery between companies and customers, for example (ATM) and hotel services (Klier et al., 2016). The reproduction of this kind of self-service has resulted in internet banking and other services, where, through automation, customers can bypass direct interaction with company employees. This kind of service will continue to grow up to be a common way of service delivery for the customer (Robertson et al., 2016b).

Self-service technology has become the modern way of delivering services to the customer instead of the traditional way of service delivery (Wang, Lin, \& Liao, 2012). This new type of self-service technology enables companies to reduce their costs due to the lower labor cost (Curran \& Meuter, 2005; Collier \& Sherrell, 2010; Klier et al., 2016), it also provides the services regardless of time and place at delivering, instead of all these things companies must take into account the usability of this technology. If this technology is not easy to use, the customer will avoid using it. Trust, security, convenience, and perceived control are the most prominent factors that enhance customer satisfaction and commitment. The current study aimed to investigate the factors that attract customers to adopt self-service technologies. Moreover, research is looking back towards the future of SST satisfaction and commitment. This research expected to enrich and extend the literature review in the field of SSTs.

\section{Related Work}

Relationship marketing is a domain which was introduced by (Berry, 1995). This 
new domain has gained the attention of scholars. Relationship marketing considers being the cornerstone of many booming enterprises. It has become more popular, especially in academic research and marketing practice. The first educational textbook about relationship marketing was released by (Christopher_ Payne_Ballantyne_1991), and the first practitioner book was published in 1991. Relationship marketing become popular and received increased visibility in terms of marketing practice and academic research in the mid-1990s, with the increase scholar's interest different themes were developed, such as AngloAustralian approach to relationship marketing, Nordic-approach to relationship marketing and North American relationship marketing approach.

Relationship marketing is establishing long term relationship with the alternative customer stakeholders, at a profit by mutual exchange and fulfillment of guarantees (Grönroos, 1994). The early definition of relationship marketing is "attracting, maintaining, and ... enhancing customer relationships" (Berry, 1995).

Relationship marketing is a theory in marketing, specifically in the B2B context (Kandampully, 2003). Services are offered differently from goods (Berry, 2002). Therefore the establishment of trust and commitment are needed in RM (Morgan \& Hunt, 1994).

Relationship marketing concentrates on increasing customer retention and loyalty (Berry, 1995). Time and money spent on attracting new customers. Customer who gets good service and care remain loyal to the organization and provide free advertisement by word-of-mouth (Rrichheld and Sasser, 1990).

Relationship marketing practices are the best way to increase customer retention in banking systems (Colgate \& Stewart, 1998), and enhancing trust, which will result in relationship commitment and satisfaction (Morgan \& Hunt, 1994). Relationship marketing pays more attention to individuals than the customer (Drew, Võ, \& Wolfe, 2013). Therefore orientation relationship marketing within B2B is more important than transactional one (Anderson \& Lehmann, 1994).

Trust, loyalty, and satisfaction are the only ways to build a stable relationship among the organizations (Morgan \& Hunt, 1994), and it is B2B's ultimate goal. Many researchers have investigated trust (Young, Boye, \& Nelson, 2006) and commitment (Cater \& Zabkar, 2009) as keys for success in relationship marketing due to service importance and the direct relationship between customers and marketers, because the nature of service, intangible and perishable it's direct to the end-users. Moreover, the customer cannot feel or see service quality (Berry, 2002). The relationship is significant in-service B2B, when the client's trust the service marketer, the customer seems to visit the same service provider (Berry, 2002). Trust has been taken as an essential element of a successful business relationship. In the study that conducted Thailand, found that trust as a primary factor for successful relationship management without trust, customer loyalty would be impossible to build, and they reinforce that trust is the most important 
factor in relationship management and bonding, empathy and reciprocity as critical component (Chattananon \& Trimetsoontorn, 2009). It's also been mentioned by (Heffernan et al., 2008) that trust is the most component for successful relationship marketing in banking services.

In a study conducted in the foodservice industry (Firdaus \& Kanyan, 2014), they tried to discover the factors that help in creating a healthy, emotional business relationship with customers. Most of the research proved that trust is the primary factor for good relationship marketing. In contrast, other authors like (Raggio et al., 2014) identified that gratitude was a significant element in a business relationship (buyers and sellers), and they determined that the gratitude expression can develop a business relationship with customers.

Businesses should not just focus on their relationship with the customer on delivering services. They should focus on relationships base on excellent customer service, and they must let customers feel confidence and appreciation within the interaction with business (Østergaard \& Fitchett 2012) this will help in forming excellent customer relationship.

\section{The Effect of Relationship Marketing on the Business}

Customers will remain loyal to the firm to pay the price even when the price increased. Due to strong excellent customer relationship (Clark, Rocco, \& Bush, 2007) while (Miquel-Romero, Caplliure-Giner, \& Adame-Sánchez, 2014) determined that relationship marketing seem to be transferable when customers feel satisfied, trust, commitment and real connection to the business, will buy another product after buying the first kind of product. Customers all over the world are looking for excellent business service and trust while they are dealing with a business. Therefore trust, commitment, empathy which can expand the business (Khojastehpour \& Johns, 2014).

The field of relationship marketing continues to gain interest from a lot of scholars due to rapid change in the global business environment. RM has been interestingly explained in profit and nonprofit firms, customers are always responding to link components trust, real connection, excellent service, commitment empathy. To remain loyal to the business, to pay the price even when the price increases. Do companies need to know what the relationship marketing future would be like?

With the global village perception for companies to compete globally, some relationship marketing determinants should be revised accordingly (Nijssen \& Herk 2009). Within mind, the business environment is different in some aspect from one place to another. (Wang, 2007) determined that Chinese Guanxi based on a personal connection, trust, loyalty, while western connection builds on impersonal. For business success, strategies should be developed according to their marketing model.

Businesses still concentrating on customers, (Madhavaram, Granot, \& Badrinarayanan, 2014) predict that business should focus on an employee with an ex- 
cellent manner of connecting customers. An employee with the ability to apply the relationship marketing components to retain customers.

The future of relationship marketing should be concentrating on using new technology to build a long-term relationship with the client. Nowadays, most of the customers are using technology to purchase their things. Therefore businesses need to create technology that keeps them close to the customers and to provide value-added on the internet to their clients (Lehtinen, 2011).

The impact of information technology on marketing is serious during the last decades (Leverick et al., 1998). IT affects business, especially market activities, handling information technology by customers has become one of the success antecedents because of the bad experience customers had during their interaction with the front line. Information technology changed the way of performing business (Brady et al., 2002). IT impact had reached most of the marketing areas beside collecting information, marketing segmentation, customer relationship management (Rust \& Espinoza, 2006). Using information technology enables the business to increase their employee's productivity. Business technology has reduced the amount of human interface in business functions. Businesses choose to relay on operational technology rather than employees if the technology has a better production output. Technology opened a new opportunity for business to reach the new economic market, rather than dealing with the local market. Information technology enables the business to be national and international market, also enable internet advertising to reach new marketing and new consumers. Business technology made it easy to companies to outsource the business function to other businesses in the national and international environment; outsourcing can help companies to reduce the cost and to focus on completing the business function they do best.

New technology has changed the way of implementing business over the past decades (Curran \& Meuter, 2005). IT made the consumers made the customer responsible of the transaction and themselves satisfaction (Bendapudi \& Leone, 2003) after training them well, to be co-producer, customers become part of value creator (Vargo \& Lusch, 2004). The broad use of the internet has an open opportunity to companies to offer self-service technology.

\section{Self-Service Technology}

The self-service technology is a kind of service that customer can use without taking the help of the employees (Robertson et al., 2016). In this kind of technology, customer can stop the transaction at any time and can do it again later (Collier \& Sherrell, 2010). By using SST customer become able to control the transaction (Collier \& Barnes, 2015). Although using SST is not easy, but the customers still feel free of the customer's pressure, it's more convenient (Robertson et al., 2016b). Although there is a lot of benefit at using SSTs, some customer still doesn't want to use this kind of service (Collier \& Barnes, 2015; Robertson et al., 2016b). Authors clarify there are so many reasons why some customers don't use 
SSTs for an example; some think that using self-service is complicated for the first time so that customers must learn how to use it. Moreover, some of the customer afraid of the security part (López-Bonilla \& López-Bonilla, 2013). Anyhow the new technology helps in reducing human errors and time; however, the future challenge of SSTs is to understand the customer to satisfy them.

\section{Theoretical Model and Research Hypothesis}

In this research, we proposed a model see Figure 1, to achieve the study, purpose, perceived trust, perceived security, perceived convenience, perceived control, customer satisfaction, and commitment.

\section{Planned Behavior Theory}

Planned behavior theory is a theory that reasoned action (Ajzen, 1991, Ajzen, 1985). It is one of the most influential models for explaining human behavior (Truong, 2009b; Chen \& Li, 2010) theory of planned behavior consider to be successful theory in guessing and explaining the human behavior across many different contexts (Truong, 2009b; López-Bonilla \& López-Bonilla, 2013). This theory had been built on consumer's attitudes and behavior's theories. It suggests that perceived control is the most significant elements for predicting costumers behaviors (Truong, 2009a; Collier \& Sherrell, 2010). Recourses are needed for individuals to engage in behavior, for example, technology accessibility. These resources represent convenience.

Perceived control can affect the customers cause for interfacing with technology, while the convenient factor stands for the facilities that help through using the technology transaction (Truong, 2009a; Collier \& Sherrell, 2010). However, self-service enables the customer to control utilizing the service. Based on the above theory and argument, we proposed the following hypotheses.

H1: There is a significant direct relationship between control factor and customer satisfaction.

\subsection{Convenience}

The benefit of technology is undeniable when it makes it easier for people to

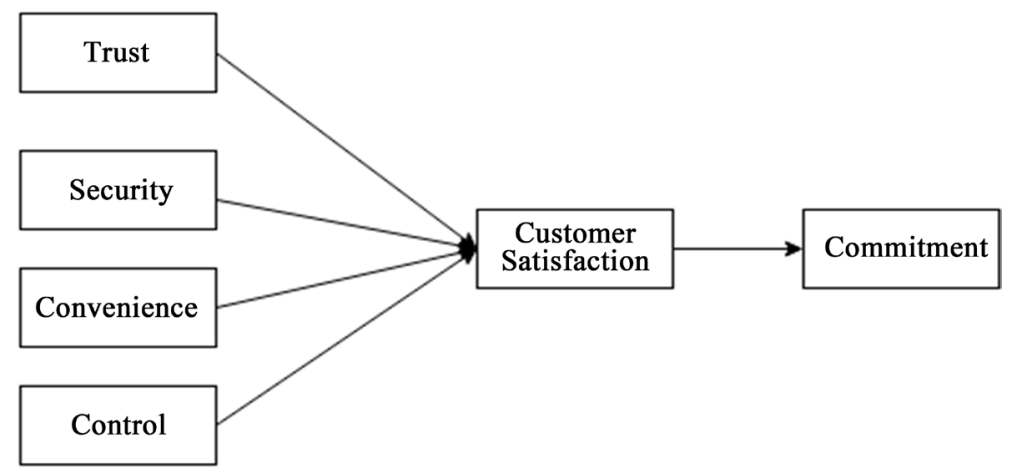

Figure 1. Research model. 
implement the task. The researcher has well-investigated convenience as a constructive factor in marketing and consumer behavior (Zhu et al., 2013; Berry, 2002). Convenience was indicated as one of the critical antecedents of the success of e-commerce (Xu \& Gutierrez, 2006). Convenience is one of the factors generating time and place for users (Clarke et al., 2001). The study conducted by (Dahlberg et al., 2007) assumed that the intention to use mobile services is affected by the circumstances of use, such as the availability of other alternatives and time pressure in the service use situations. Based on the above, we proposed the following hypotheses.

$\mathrm{H}: 2$ there is a significant relationship between the convenience factor and customer satisfaction.

\subsection{Trust and Security}

Security and trust are the most critical factors in self-services, especially in e-commerce (Chen \& He, 2003; Warkentin et al., 2002). Security is defined as the system's ability to protect the user's data from the unauthorized source during the online transaction (Guo et al., 2012). Security considered a vital factor for online purchasing (Eid, 2011). Security and privacy play an essential role in creating trust during self-service online transactions (Chellappa, 2002). Customers are willing to buy online if only they are confident to provide their personal information (Whysall, 2000). Customers tend to purchase from a vendor that they trust or products that familiars with (Chen \& He, 2003). Security considers, being one of the problematic factors that prevent customers from using self-services (Laudon \& Traver, 2017). In e-commerce trust integrated with reliability (Yang et al., 2015) and system security (Oliveira et al., 2017), the trust may change the user's perception toward using self-services. Security and trust are self-services determinants, directly related to customer satisfaction (George \& Kumar, 2013). Trust affects individuals to use self-services (Khoa, 2020; Dahlberg et al., 2007). Thus, any secure payment can have a reliable and satisfied customer; based on the above, the following research hypothesis is defined.

H3: There is a significant relationship between trust factor and customer satisfaction.

H4: There is a significant relationship between security factor and customer satisfaction.

\subsection{Customer Satisfaction and Commitment}

It is one of the most critical issues that attracted the attention of the business organization of all types, which is justified by the customer-oriented philosophy and continues improvement principles of the modern enterprise (Arokiasamy, n.d.). Having a good relationship with the customer will influence the service provider (Panda, 2003), which will result in customer loyalty (Jones et al., 2002). It has been proved that the cost of attracting a new customer is high five times the cost of retaining the current customer (Kotler \& Rackham, n.d.; 
Teich 1997). According to (Oliver, 2014, Boateng, 2020), satisfaction is defined as a state of expectation and the actual performance of the product. Customer satisfaction is also defined as "overall customer evaluation of the performance of an offering to date," according to (Anderson, Fornell, \& Lehmann, 1994). Satisfaction can drive the customer to behaviors of loyalty and positive word of mouth (Abdul-Mauhmin, 2002). Therefore, for firms to improve customer satisfaction and commitment need to research the factors that impacting customer satisfaction and reusing the product/service and achieve loyalty by satisfying the customer. Customer satisfaction considers as a measure for describing how the product/service meets the customer expectations, and it is an essential element for ensuring successful business because satisfaction can reflect the firm growth in the future. However, the dimensions of satisfaction, and trust, were the most common variables in the relationship marketing studies for achieving customer commitment (Abosag et al., 2006), these dimensions are also relevant in the context of e-commerce. Based on the above, the following hypothesis was proposed.

H5: There is a significant relationship between customer satisfaction and customer commitment.

\section{Methodology}

This survey was conducted in Xi'an, China, the sample of 200 questionnaires, was distributed to the target samples, 149 questionnaires found to be useful for the analysis. The survey targeted the users of ATM as one of the self-service technologies. Two experts and one specialist reviewed the questionnaire. The researcher distributed 30 questionnaires to the targeted samples for the initial application.

Inner consistency between items showed a strong relationship between each item and dimensions and entire items of the questionnaire, which showed that the highest correlation value was (0.825) and the lowest value was (0.331) for the reliability and validity, root square was used see Table 1.

The square root of $\alpha$ that used to determine the validity $=\sqrt{\alpha}$ (Smits, Ark, \& Conijn, 2017) which indicate that reliability and validity values were acceptable

Table 1. Validity and reliability.

\begin{tabular}{cccccc}
\hline Contents & No of items & Validity $=\sqrt{\alpha}$ & Reliability $(\alpha)$ & CR & AVE \\
\hline Control factor & 5 & 0.938 & 0.881 & 0.813 & 0.723 \\
Convenience factor & 5 & 0.966 & 0.933 & 0.891 & 0.791 \\
Trust factor & 5 & 0.947 & 0.897 & 0.835 & 0.771 \\
Customer satisfaction & 4 & 0.913 & 0.833 & 0.823 & 0.783 \\
Customer commitment & 7 & 0.937 & 0.878 & 0.811 & 0.691 \\
Overall & 26 & 0.957 & 0.917 & 0.863 & 0.801 \\
\hline
\end{tabular}

Note: $\alpha=$ Cronbach's Alpha AVE = Average Variance Extracted, CR = Composite Reliability. 
as specified by (Heale \& Twycross, 2015). The AVE found to be higher than 0.50 , which is an indication of suitable approximate validity (Hair et al., 2014).

Data was collected in China by the survey from those who have a bank account. They are self-service users, and the questionnaire was written in English and then translated to the Chinese language the questionnaire includes a series of statements. The respondent was asked to point their degree of consent with every statement; the sample was scored on a five-point scale: 1 for "strongly disagree" 2 for "disagree" 3 for "neutral" 4 for "agree" 5 for "strongly agree" all questionnaire items were drawn from previous studies (Meuter et al., 2000; Mumin, Ustarz, \& Yakubu, 2014).

\section{Results}

The demographic data in Table 2 show that the respondents were female $53 \%$ and $47 \%$ male; the majority of the respondents were between the ages of 20 40.

The research used descriptive statistic to clarify the collected data features in quantitative terms. It used to test the data in term of mean, median and standard deviation. The questionnaires and all items based on five points Likert scale; the mean value was found to be 53.3788 for all five dimensions are showing the significant positive relationship. While the standard deviation was 3.44086 for all five dimensions see Table 3.

The correlation analysis is used to find the relationship between the determinants; the correlation analysis results show that significant positive relationship between control factor and customer satisfaction (0.505), positive relationship between convenience factor and customer satisfaction (0.617), positive relationship,

Table 2. Demographic data.

\begin{tabular}{cccccccc}
\hline Gender & $\mathrm{N}$ & Percentage $\%$ & $\mathrm{M}$ & $\mathrm{SD}$ & $\mathrm{T}$-Test & $\mathrm{DF}$ & Sig \\
\hline Male & 70 & 47 & 56.6571 & 19.41752 & & & \\
Female & 79 & 53 & 50.4684 & 15.49511 & & & \\
\hline
\end{tabular}

$\left.{ }^{*}\right) \rho<0.05$.

Table 3. Descriptive statistics.

\begin{tabular}{cccc}
\hline Contents & $\mathrm{N}$ & $\mathrm{M}$ & $\mathrm{SD}$ \\
\hline Control & & 9.0805 & 3.19103 \\
Convenience & & 9.8121 & 4.08420 \\
Trust & & 8.5772 & 3.28835 \\
Security & 149 & 9.5772 & 3.26981 \\
Satisfaction & & 10.4698 & 3.56135 \\
Commitment & & 5.8389 & 3.44075 \\
Overall & \multirow{2}{*}{149} & 53.3788 & 3.444086
\end{tabular}


there is a strong positive relationship between trust factor and customer satisfaction (0.688), there is a significant positive relationship between security and satisfaction (0.394), customer satisfaction showed a solid relationship with commitment (0.812).

The regression is used to determine the dependence of customer satisfaction upon the independent variables, control, convenient factor, ATM trust, security, commitment. The result showed that the finding showed up to 0.658 of (customer satisfaction) is clarifying by the five predicting variables, the value of beta found as commitment 0.812 , trust 0.688 , convenience factor 0.617 , control factor 0.505 , security 0.394 research found that customer satisfaction is the most commitment underpin.

For the efficiency there are strong effects between control factors on satisfaction (0.505), convenient factor on satisfaction (0.617), trust factor on satisfaction (0.688), security on satisfaction (0.394), satisfaction on commitment (0.812).

\section{Discussion}

Our study framework contribution offers a deep conception of the antecedents influencing user's satisfaction and commitment among Chinese users, this study provides a further understanding of forming satisfaction and commitment in Self-service technology in China. Moreover, the study investigates several important factors that influencing satisfaction and commitment.

Self-service technology is a kind of service delivery which growing on all types of the industry. Mostly in China, nowadays, self-service is hugely used in most of the business sector. The purpose of this paper is to identify the IT impact on marketing relationship and to extend the understanding of satisfaction and commitment driver in the bank's industry (SST-ATM) and show the effect of the information technology on customer satisfaction and commitment in China, Shaanxi province.

In this part the research discussed the relationship among the factors as it appeared in Figure 2, control factor found to have a significant positive relationship

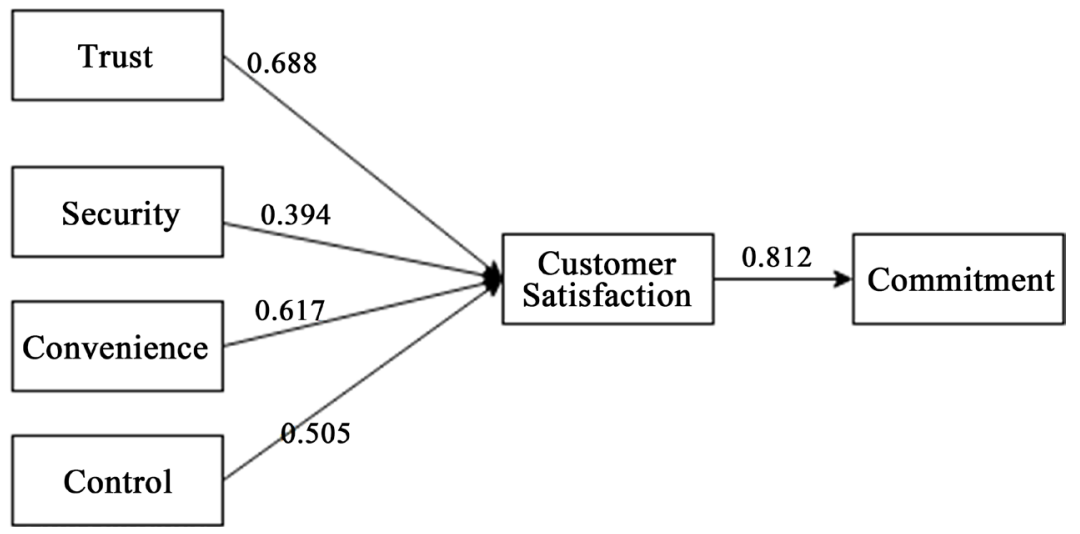

Figure 2. The correlation among the factors. 
with satisfaction (0.505), which agreed with (Truong, 2009a; Collier \& Sherrell, 2010; Chen \& Li, 2010) perceive control one of the most important factor for predicting customer behavior and satisfaction, it is a factor that leadsthe customer to use ATM. (Walker et al., 2002; Howard \& Worboys, 2003; Lopez-Bonilla \& Lopez-Bonilla, 2014) found that control is one of the factors that influence customers to use ATMs. Control is the core factor of interaction between the human and the technology (Collier \& Barnes, 2015; Schmitz, Bartsch, \& Meyer, 2016). In the study conducted by (Mohammed et al., 2016) result found that control factor did not have an impact on the customer hedonic value. This result is contradicting our study maybe this due to different environment and culture his study conducted in Sweden and our study conducted in China every society have different perception toward technology. Different SST will be affected by different factors (Klier et al., 2016; Robertson et al., 2016).

Convenience has found to be one of the factors that drive the customer to use ATMs. It had a significant relationship with customer satisfaction (0.617). Self-service technology made business very convenient and reduced the cost, as well solved the time problem, this finding consents with (Mumin, Ustarz, \& Yakubu 2014; Pahwa et al., 2011) found that convenient is the crucial factor for customer decision to use ATM. When convenience increases, the customer would prefer to serve themselves instead of asking employees (Collier \& Barnes, 2015; Chen \& Li, 2010). Therefore, the customer will not use self-service technology (ATM) if it is not convenient to use. Convenience within SSTs is about the effort that customer will do to use SSTs regarding the time that will be spending (Zhu, Nakata, \& Sivakumar, 2007; Collier \& Barnes, 2015). The convenience factor has been confirmed by numerous authors such as (Meuter et al., 2000; Collier \& Barnes, 2015; Klier et al., 2016). In the study conducted by (Collier \& Barnes, 2015; Ding, Hu, \& Sheng, 2011) found that convenience one of the most important factor for the customer when estimating ATM (SSTs).

Trust found to have the strongest positive relationship with satisfaction (0.688), trust leads to loyalty directly and indirectly, and it encourages the customer to use the ATM service (Chaudhuri \& Holbrook, 2001). In a study conducted by (Veerakumar, 2016) found that trust affects customer loyalty. In the case of China and Germany, cultures found that trust has a strong relationship with customer loyalty (Cyr, 2008). In the study that conducted by (Qu et al., 2018) found that lower trust leads people not to use the service, if the service provider is not the trustworthy customer would not tend to use the service trust is the foundation of financial transaction (Llewellyn, 2005).

Security had found to have a significant relationship with satisfaction (0.394) in ATM usage. Still, less than the three other factors, in this study customer considered security as an indirect factor for their satisfaction within ATM. However, trust was found as strong customer driver for satisfaction which results in customer commitment, the finding of this study consent with (Eid, 2011; Qu et al., 
2018). Trust is influenced by security, according to (Flavia, Guinal1, \& Casalo, 2007). Customer who feels comfortable and secured at using ATM tend to use more than others (Mumin, Ustarz, \& Yakubu, 2014).

Customer satisfaction has found to have the strongest relationship with customer commitment (0.812). Customer satisfaction has the largest impact on customer commitment this come in line with (Walsh et al., 2010) according to (Soni et al., 1996) satisfaction creates a positive impact on commitment. If the customers are satisfied with the services that offer by ATM, they will keep using the same service unless a better and more convenient technology appears to replace the current one.

Finally, The outcome of this study shows that the four factors (control, convenience, trust, security) have the greatest impact on customer satisfaction and commitment where all of them were accepted significant level (see Table 4) the fifth hypothesis was accepted. The previous studies finding show the strong impact of the customer utilizing the private SST-ATM (Farquhar \& Rowley, 2009; Collier \& Kimes, 2013), the result of this study found that the four dimensions have a strong impact toward the customer satisfaction which resulted on commitment, the beta values of trust found to be higher on the linear regression analysis (see Table 4) also for the adjusted R-Square trust found to be higher (see Table 4) this emphasizes that trust has a greater impact on customer satisfaction.

The multiple regression analysis measured if the satisfaction is derived from the four factors (control, convenience, trust, security) have the higher impact on customer satisfaction, and commitment, as can be seen in Table 4 customer satisfaction significantly accepted at (0.000) and commitment at $(0.000)$, this reference to that customer satisfaction, have a significantly impacted the customer commitment in ATM this support the previous studies of (Strombeck \& Wakefield, 2008; Eriksson \& Nilsson, 2007).

Customer satisfaction shows a significant relationship with commitment (0.000). This reflects that customer satisfaction has the greatest impact on customer commitment (0.812) for using ATM. Additionally, the beta for the

Table 4. Correlation and regression.

\begin{tabular}{|c|c|c|c|c|c|c|c|}
\hline Independent variable & Dependent & $\mathrm{R}$ & Adjusted R & Beta $\beta$ & $\mathrm{F}$ & T-Test & Sig \\
\hline Control & Satisfaction & 0.505 & 0.250 & 0.505 & ----- & $7.086^{\star * *}$ & 0.000 \\
\hline Convenient & Satisfaction & 0.617 & 0.377 & 0.617 & ----- & $9.509^{* * *}$ & 0.000 \\
\hline Trust & Satisfaction & 0.688 & 0.470 & 0.688 & ----- & $11.509^{* * *}$ & 0.000 \\
\hline Security & Satisfaction & 0.394 & 0.149 & 0.394 & ------ & $5.196^{* * *}$ & 0.000 \\
\hline Satisfaction & Commitment & 0.812 & 0.658 & 0.812 & ------ & $16.890^{\star * *}$ & 0.000 \\
\hline Whole dimensions & Satisfaction & 0.793 & 0.626 & 0.793 & $249.064^{\star * *}$ & ------ & 0.000 \\
\hline
\end{tabular}


commitment was (0.812), and the $\mathrm{R}$ square was (0.658). The satisfaction that derived from ATM will greatly impact the commitment, according to (Wolfinbarger, n.d.) Who has mentioned that for the customer to use the self-service technology (ATM)? The ATM transaction must be easy, and the process must be controllable according to the customer needs and want. It was argued that customers using SSTs because of the convenience factor, the customer uses less facility and gets the higher and fast quality transaction which is related to the satisfaction (Collier et al., 2014).

\section{Limitations and Future Research}

Although this research has revealed a useful finding, but there is still some limitation in this work, the data of this study collected in China Xi'an city and most of the respondents were university students. Therefore, attention should be paid when generalizing the finding of this study, to other different groups of ages or different cultural environments. More samples are needed; this research focused on ATM as one of the SSTs, future research should be the focus on other different SSTs.

\section{Conclusion}

Although the area of relationship marketing and information technology impact on satisfaction has been issued in academic research, the field seems to be increasingly relevant in extremely complicated and multifarious relationships that presently these days.

Information technology has foster companies to develop their marketing mix that is able to satisfy their customer's needs. Recently businesses realize that the ultimate customer's value is not always the lower price, but also other aspects delivery, brand associations, relevant to customers become increasingly important, when the market change to growth slows or when marketing competition becomes severe, marketers focusing more and more on retaining current customers (Kacen \& Lee, 2002).

As marketing is extending the use of technology more increasing and more important. The correlation between marketing and the role of informatics becomes more positive. Every day we have new technology which is trying to satisfy customer's needs, the business needs to develop, new hypotheses and theories to suit this new trend. The finding of this research supports the hypotheses that control, convenience, ATM trust and security have a strong impact on customer satisfaction, which will drive customer commitment. The research proved that information technology has a great impact on customer satisfaction.

\section{Conflicts of Interest}

The authors declare no conflicts of interest regarding the publication of this paper. 


\section{References}

Abdul-Mauhmin, A. G. (2002). Effects of Suppliers Marketing Program Variables on Industrial Buyer Relationship Satisfaction and Commitment. Journal of Business \& Industrial Marketing, 17, 637-651. https://doi.org/10.1108/08858620210451136

Abosag, I., Tynan, C., \& Lewis, C. (2006). The Commitment-Trust Theory: The British and Saudi Arabian Cross-National Perspectives. Journal of Business \& Industrial Marketing, No. 1994, 1-24.

Ajzen, I. (1985). From Intentions to Actions: A Theory of Planned Behavior. In J. Kuhl, \& J. Beckmann (Eds.), Action Control (pp. 11-39). Berlin: Springer.

https://doi.org/10.1007/978-3-642-69746-3 2

Ajzen, I. (1991). The Theory of Planned Behavior. Organizational Behavior and Human Decision Processes, 2, 179-211. https://doi.org/10.1016/0749-5978(91)90020-T

Anderson, F., \& Lehmann, D. (1994). Customer Satisfaction, Market Share, and Profitability: Findings from Sweden. Journal of Marketing, 58, 53-66. https://doi.org/10.1177/002224299405800304

Arokiasamy, A. R. A. (2013). The Impact of Customer Satisfaction on Customer Loyalty and Intentions to Switch in the Banking Sector in Malaysia. The Journal of Commerce, $5,14-21$.

Bendapudi, N., \& Leone, P. R. (2003). Psychological Implications of Customer Participation in Co-Production. Journal of Marketing, 67, 14-28.

https://doi.org/10.1509/jmkg.67.1.14.18592

Berry, L. L. (1995). Relationship Marketing of Services-Growing Interest, Emerging Perspectives. Journal of the Academy of Marketing Science, 23, 236-245. https://doi.org/10.1177/009207039502300402

Berry, L. L. (2002). Relationship Marketing of Services Perspectives from 1983 and 2000. Journal of Relationship Marketing, 1, 59-77. https://doi.org/10.1300/J366v01n01 05

Boateng, S. L. (2020). Enhancing Calculative Commitment and Customer Loyalty through Online Relationship Marketing: The Mediating Role of Online Trust. In Advanced MIS and Digital Transformation for Increased Creativity and Innovation in Business (pp. 50-76). Hershey, PA: IGI Global. https://doi.org/10.4018/978-1-5225-9550-2.ch003

Brady, M., Saren, M., \& Tzokas, N. (2002).Integrating Information Technology into Marketing Practice: The IT Reality of Contemporary Marketing Practice. Journal of Marketing Management, 18, 555-577.

Cater, B., \& Zabkar, V. (2009). Antecedents and Consequences of Commitment in Marketing Research Services: The Client's Perspective. Industrial Marketing Management, 38, 785-797. https://doi.org/10.1016/j.indmarman.2007.10.004

Chattananon, A., \& Trimetsoontorn, J. (2009). Relationship Marketing: A Thai Case. International Journal of Emerging Markets, 4, 252-274.

https://doi.org/10.1108/17468800910968418

Chaudhuri, A., \& Holbrook, M. B. (2001). The Chain of Effects from Brand Trust and Brand Affect to Brand Performance: The Role of Brand Loyalty. Journal of Marketing, 65, 81-93. https://doi.org/10.1509/jmkg.65.2.81.18255

Chellappa, R. K. (2002). Consumers' Trust in Electronic Commerce Transactions: The Role of Perceived Privacy and Perceived Security (pp. 1-38). Thesis.

Chen, R., \& He, F. (2003). Examination of Brand Knowledge, Perceived Risk and Con- 
sumers' Intention to Adopt an Online Retailer. Total Quality Management and Business Excellence, 14, 677-693. https://doi.org/10.1080/1478336032000053825

Chen, S., \& Li, S. (2010). Consumer Adoption of E-Service: Integrating Technology Readiness with the Theory of Planned Behavior. African Journal of Business Management, 4, 3556-3563.

Christopher_Payne_Ballantyne_1991.Pdf. n.d.

Clark, P., Rocco, R., \& Bush, A. J. (2007). Sales Force Automation Systems and Sales Force Productivity: Critical Issues and Research Agenda. Journal of Relationship Marketing, 6, 67-88. https://doi.org/10.1300/J366v06n02 06

Clarke, C. J., Gendrin, A., \& Sotomayor, M. (2001). The Dispersal of Circumstellar Discs: the Role of the Ultraviolet Switch. Monthly Notices of the Royal Astronomical Society, 328, 485-491.

Colgate, M., \& Stewart, K. (1998). The Challenge of Relationships in Services-A New Zealand Study. International Journal of Service Industry Management, 9, 454-468. https://doi.org/10.1108/09564239810238857

Collier, J. E., \& Barnes, D. C. (2015). Self-Service Delight: Exploring the Hedonic Aspects of Self-Service. Journal of Business Research, 68, 986-993. https://doi.org/10.1016/j.jbusres.2014.09.036

Collier, J. E., \& Kimes, S. E. (2013). Only If It Is Convenient. Journal of Service Research, 16, 39-51. https://doi.org/10.1177/1094670512458454

Collier, J. E., \& Sherrell, D. L. (2010). Examining the Influence of Control and Convenience in a Self-Service Setting. Journal of the Academy of Marketing Science, 38, 490-509. https://doi.org/10.1007/s11747-009-0179-4

Collier, J. E., Sherrell, D. L., Babakus, E., \& Horky, A. B. (2014). Understanding the Differences of Public and Private Self-Service Technology. Journal of Services Marketing, 28, 60-70. https://doi.org/10.1108/JSM-04-2012-0071

Curran, J. M., \& Meuter, M. L. (2005). Self-Service Technology Adoption: Comparing Three Technologies. Journal of Services Marketing, 19, 103-113. https://doi.org/10.1108/08876040510591411

Cyr, D. (2008). Modeling Web Site Design across Cultures: Relationships to Trust, Satisfaction, and E-Loyalty. Journal of Management Information Systems, 24, 47-72. https://doi.org/10.2753/MIS0742-1222240402

Dahlberg, T., Mallat, N., Ondrus, J., \& Zmijewska, A. (2007). Past, Present and Future of Mobile Payments Research: A Literature Review. Electronic Commerce Research and Applications, 7, 165-181. https://doi.org/10.1016/j.elerap.2007.02.001

Ding, D. X., Hu, P. J. H., \& Sheng, O. R. L. (2011). E-SELFQUAL: A Scale for Measuring Online Self-Service Quality. Journal of Business Research, 64, 508-515. https://doi.org/10.1016/j.jbusres.2010.04.007

Drew, T., Võ, M. L. H., \& Wolfe, J. M. (2013). The Invisible Gorilla Strikes Again: Sustained Inattentional Blindness in Expert Observers. Psychological Science, 24, 1848-1853. https://doi.org/10.1177/0956797613479386

Eid, M. I. (2011). Determinants of E-Commerce Customer Satisfaction, Trust, and Loyalty in Saudi Arabia. Journal of Electronic Commerce Research, 12, 78-93.

Eriksson, K., \& Nilsson, D. (2007). Determinants of the Continued Use of Self-Service Technology: The Case of Internet Banking. Technovation, 27, 159-167. https://doi.org/10.1016/j.technovation.2006.11.001 
Farquhar, J. D., \& Rowley, J. (2009). Convenience: A Services Perspective. Marketing Theory, 9, 425-438. https://doi.org/10.1177/1470593109346894

Firdaus, A., \& Kanyan, A. (2014). Managing Relationship Marketing in the Food Service Industry. Marketing Intelligence and Planning, 32, 293-310. https://doi.org/10.1108/MIP-10-2012-0116

Flavia, C., Guinal, M., \& Casalo, L. V. (2007). The Role of Security, Privacy, Usability and Reputation in the Development of Online Banking. Online Information Review, 31, 583-603. https://doi.org/10.1108/14684520710832315

George, A., \& Kumar, G. S. G. (2013). Antecedents of Customer Satisfaction in Internet Banking: Technology Acceptance Model (TAM) Redefined. Global Business Review, 14, 627-638. https://doi.org/10.1177/0972150913501602

Grönroos, C. (1994). From Scientific Management to Service Management: A Management Perspective for the Age of Service Competition. International Journal of Service Industry Management, 5, 5-20. https://doi.org/10.1108/09564239410051885

Guo, X., Ling, K. C., \& Liu, M. (2012). Evaluating Factors Influencing Customer Satisfaction towards Online Shopping in China. Asian Social Science, 8, 40-50. https://doi.org/10.5539/ass.v8n13p40

Hair, J. F., Black, W. C., Babin, B. J., Anderson, R. E., \& Tatham, R. L. (2014). Pearson New International Edition. In Multivariate Data Analysis (7th Edition). Essex: Pearson Education Limited Harlow.

Heale, R., \& Twycross, A. (2015). Validity and Reliability in Qualitative Studies. Evidence-Based Nursing, 18, 66-67. https://doi.org/10.1136/eb-2015-102129

Heffernan, T., O’Neill, G., Travaglione, T., \& Droulers, M. (2008). Relationship Marketing: The Impact of Emotional Intelligence and Trust on Bank Performance. International Journal of Bank Marketing, 26, 183-199. https://doi.org/10.1108/02652320810864652

Howard, M., \& Worboys, C. (2003). Self-Service-A Contradiction in Terms or Customer-Led Choice? Journal of Consumer Behaviour, 2, 382-392.

https://doi.org/10.1002/cb.115

Jones, M. A., Mothersbaugh, D. L., \& Beatty, S. E. (2002). Why Customers Syat: Measuring the Underlying Dimensions of Services Switching Costs and Managing Their Differential Strategic Outcomes. Journal of Business Research, 55, 441-450. https://doi.org/10.1016/S0148-2963(00)00168-5

Kacen, J. J., \& Lee, J. A. (2002). The Influence of Culture on Consumer Impulsive Buying Behavior. Journal of Consumer Psychology, 12, 163-176. https://doi.org/10.1207/S15327663/CP1202 08

Kandampully, J. (2003). B2B Relationships and Networks in the Internet Age. Management Decision, 41, 443-451. https://doi.org/10.1108/00251740310479296

Khoa, B. T. (2020). The Antecedents of Relationship Marketing and Customer Loyalty: A Case of the Designed Fashion Product. Journal of Asian Finance Economics and Business, 7, 195-204. https://doi.org/10.13106/jafeb.2020.vol7.no2.195

Khojastehpour, M., \& Johns, R. (2014). The Effect of Environmental CSR Issues on Corporate/Brand Reputation and Corporate Profitability. European Business Review, 26, 330-339. https://doi.org/10.1108/EBR-03-2014-0029

Klier, J., Klier, M., Müller, A. L., \& Rauch, C. (2016). The Impact of Self-Service Technologies-Towards an Economic Decision Model and Its Application at the German Federal Employment Agency. Journal of Decision Systems, 25, 151-172. 
https://doi.org/10.1080/12460125.2016.1141274

Kotler, P., \& Rackham, N. (n.d.). Ending the War between Sales and Marketing.

Kotler, P., Armstrong, G., Harris, L. C., \& Piercy, N. (2013). Principles of Marketing European Edition.

Laudon, K. C., \& Traver, C. G. (2017). E-Commerce.

Lehtinen, U. (2011). Combining Mix and Relationship Marketing. The Marketing Review, 11, 117-136. https://doi.org/10.1362/146934711X589363

Leverick, F., Littler, D., Bruce, M., \& Wilson, D. (1998). Using Information Technology Effectively: A Study of Marketing Installations. Journal of Marketing Management, 14, 927-962. https://doi.org/10.1362/026725798784867554

Llewellyn, D. T. (2005). Trust and Confidence in Financial Services: A Strategic Challenge. Journal of Financial Regulation and Compliance, 13, 333-346.

López-Bonilla, J. M., \& López-Bonilla, L. M. (2013). Exploring the Relationship between Social Networks and Collaborative Learning. British Journal of Educational Technology, 44, 2011-2014. https://doi.org/10.1111/bjet.12003

Lopez-Bonilla, J. M., \& Lopez-Bonilla, L. M. (2014). Validation of the Need for Social Interaction Scale between Customer and Service Provider. Rbgn-Revista Brasileira De Gestao De Negocios, 16, 560-574. https://doi.org/10.7819/rbgn.v16i53.1622

Madhavaram, S., Granot, E., \& Badrinarayanan, V. (2014). Relationship Marketing Strategy: An Operant Resource Perspective. Journal of Business and Industrial Marketing, 29, 275-283. https://doi.org/10.1108/JBIM-02-2013-0049

Meuter, M. L., Ostrom, A. L., Roundtree, R. I., \& Bitner, M. J. (2000). Self-Service Technologies: Understanding Customer Satisfaction with Technology-Based Service Encounters. Journal of Marketing, 64, 50-64. https://doi.org/10.1509/jmkg.64.3.50.18024

Miquel-Romero, M. J., Caplliure-Giner, E. M., \& Adame-Sánchez, C. (2014). Relationship Marketing Management: Its Importance in Private Label Extension. Journal of Business Research, 67, 667-672. https://doi.org/10.1016/j.jbusres.2013.11.025

Mohammed, A., Kong, X. J., Liu, L., Xia, F., Abolfazli, S., Sanaei, Z., \& Tolba, A. (2016). BoDMaS: Bio-Inspired Selfishness Detection and Mitigation in Data Management for Ad-Hoc Social Networks. Ad Hoc Networks, 1-13.

https://doi.org/10.1016/j.adhoc.2016.09.013

Morgan, R. M., \& Hunt, S. D. (1994). The Commitment-Trust Theory of Relationship Marketing. Journal of Marketing, 58, 20-38.

https://doi.org/10.1177/002224299405800302

Mumin, Y. A., Ustarz, Y., \& Yakubu, I. (2014). Automated Teller Machine (ATM) Operation Features and Usage in Ghana: Implications for Managerial Decisions. Journal of Business Administration and Education, 5, 137-157.

Nijssen, E. J., \& van Herk, H. (2009). Conjoining International Marketing and Relationship Marketing: Exploring Consumers' Cross-Border Service Relationships. Journal of International Marketing, 17, 91-115. https://doi.org/10.1509/jimk.17.1.91

Nijssen, E. J., Schepers, J. J. L., \& Belanche, D. (2016). Why Did They Do It? How Customers' Self-Service Technology Introduction Attributions Affect the Customer-Provider Relationship. Journal of Service Management, 27, 276-298. https://doi.org/10.1108/JOSM-08-2015-0233

Oliveira, T., Thomas, M., Baptista, G., \& Campos, F. (2017). Computers in Human Behavior Mobile Payment: Understanding the Determinants of Customer Adoption and In- 
tention to Recommend the Technology. Computers in Human Behavior, 61, 404-414. https://doi.org/10.1016/j.chb.2016.03.030

Oliver, R. L. (2014). Whence Consumer Loyalty? Journal of Marketing, 63, 33-44. https://doi.org/10.2307/1252099

Østergaard, P., \& Fitchett, J. (2012). Relationship Marketing and the Order of Simulation. Marketing Theory, 12, 233-249.

Pahwa, M. S., \& Saxena, K. (2011). Analytical Study of Customer Satisfaction at ICICI Bank with Special Reference to ATMs. 2011 3rd International Conference on Information and Financial Engineering IPEDR, vol. 12, 160-164.

Panda, T. K. (2003). Creating Customer Lifetime Value through Effective CRM in the Financial Services Industry. Journal of Services Research, 22, 157-171.

Qu, Y., Rong, W., Chen, H., Ouyang, Y. X., \& Xiong, Z. (2018). Influencing Factors Analysis for a Social Network Web Based Payment Service in China. Journal of Theoretical and Applied Electronic Commerce Research, 13, 99-113. https://doi.org/10.4067/S0718-18762018000300106

Raggio, R. D., Walz, A. M., Godbole, M. B., \& Folse, J. A. G. (2014). Gratitude in Relationship Marketing: Theoretical Development and Directions for Future Research. $\mathrm{Eu}-$ ropean Journal of Marketing, 48, 2-24. https://doi.org/10.1108/EJM-08-2009-0355

Robertson, A. L., Ogryzko, N. V., Henry, K. M., Loynes, C. A., Foulkes, M. J., Meloni, M. M., Wang, X. et al. (2016a). Identification of Benzopyrone as a Common Structural Feature in Compounds with Anti-Inflammatory Activity in a Zebrafish Phenotypic Screen. Disease Models \& Mechanisms, 9, 621-632. https://doi.org/10.1242/dmm.024935

Robertson, S. A., Datu, J. A. D., Brawley, A. M., Pury, C. L. S., \& Mateo, N. J. (2016b). The Dark Triad and Social Behavior: The Influence of Self-Construal and Power Distance. Personality and Individual Differences, 98, 69-74. https://doi.org/10.1016/j.paid.2016.03.090

Rrichheld, F. F., \& Sasser, W. E. (1990). Zero Defeofions: Quoliiy Comes to Services. Harvard Business Review, 68, 105-111.

Rust, R. T., \& Espinoza, F. (2006). How Technology Advances Influence Business Research and Marketing Strategy. Journal of Business Research, 59, 1072-1078. https://doi.org/10.1016/j.jbusres.2006.08.002

Schmitz, C., Bartsch, S., \& Meyer, A. (2016). Mobile App Usage and Its Implications for Service Management-Empirical Findings from German Public Transport. Procedia-Social and Behavioral Sciences, 224, 230-237. https://doi.org/10.1016/j.sbspro.2016.05.492

Sheth, J. N. (2002). The Future of Relationship Marketing. Journal of Services Marketing, 16, 590-592. https://doi.org/10.1108/08876040210447324

Smits, N., Van Der Ark, L. A., \& Conijn, J. M. (2017). Measurement versus Prediction in the Construction of Patient-Reported Outcome Questionnaires: Can We Have Our Cake and Eat It ? Quality of Life Research, 27, 1673-1682. https://doi.org/10.1007/s11136-017-1720-4

Soni, P. K., Wilson, D. T., \& O’Keefe, M. (1996). Beyond Customer Satisfaction: Customer Commitment. Institute for the Study of Business Markets, Pennsylvania State University.

Strombeck, S. D., \& Wakefield, K. L. (2008). Situational Influences on Service Quality Evaluations. Journal of Services Marketing, 22, 409-419. 


\section{https://doi.org/10.1108/08876040810889175}

Teich, I. (1997). Holding on to Customers: The Bottom-Line Benefits of Relationship Building. Bank Marketing, 29, 12-13.

Truong, Y. (2009a). An Evaluation of the Theory of Planned Behaviour in Consumer Acceptance of Online Video and Television Services. Electronic Journal Information Systems Evaluation, 12, 177-186.

Truong, Y. (2009b). An Evaluation of the Theory of Planned Behaviour in Consumer Acceptance of Online Video and Television Services Assistant Professor of Marketing. The Electronic Journal Information Systems Evaluation, 12, 177-186.

Vargo, S. L., \& Lusch, R. F. (2004). Evolving to a New Dominant Logic for Marketing. Journal of Marketing, 68, 1-17. https://doi.org/10.1509/jmkg.68.1.1.24036

Veerakumar, K. (2016). A Research on Quality Factors Influencing Online Shopping. International Journal of Engineering Research and Modern Education, 1, 1.

Walker, M. P., Brakefield, T., Morgan, A., Hobson, J. A., \& Stickgold, R. (2002). Practice with Sleep Makes Perfect. Neuron, 35, 205-211. https://doi.org/10.1016/S0896-6273(02)00746-8

Walsh, G., Hennig-Thurau, T., Sassenberg, K., \& Bornemann, D. (2010). Does Relationship Quality Matter in E-Services? A Comparison of Online and Offline Retailing. Journal of Retailing and Consumer Services, 17, 130-142. https://doi.org/10.1016/j.jretconser.2009.11.003

Wang, C. L. (2007). Guanxi vs. Relationship Marketing: Exploring Underlying Differences. Industrial Marketing Management, 36, 81-86. https://doi.org/10.1016/j.indmarman.2005.08.002

Wang, Y.-S., Lin, H.-H., \& Liao, Y.-W. (2012). Investigating the Individual Difference Antecedents of Perceived Enjoyment in Students' Use of Blogging. British Journal of Educational Technology, 43, 139-152. https://doi.org/10.1111/j.1467-8535.2010.01151.x

Warkentin, M., Gefen, D., Pavlou, P. A., \& Rose, G. M. (2002). Encouraging Citizen Adoption of E-Government by Building Trust. Electronic Markets, 12, 157-162. https://doi.org/10.1080/101967802320245929

Whysall, P. (2000). Retailing and the Internet: A Review of Ethical Issues. International Journal of Retail \& Distribution Management, 28, 481-489. https://doi.org/10.1108/09590550010356840

Wolfinbarger, M. (n.d.). That Values the Consumer Web Experiential Marketing.

Xu, G., \& Gutiérrez, J. A. (2006). An Exploratory Study of Killer Applications and Critical Success Factors in M-Commerce. Journal of Electronic Commerce in Organizations (JECO), 4, 63-79.

Yang, Q., Pang, C., Liu, L., Yen, D. C., \& Tarn, J. M. (2015). Computers in Human Behavior Exploring Consumer Perceived Risk and Trust for Online Payments: An Empirical Study in China's Younger Generation. Computers in Human Behavior, 50, 9-24. https://doi.org/10.1016/j.chb.2015.03.058

Young, E. L., Boye, A. E., \& Nelson, D. A. (2006). Relational Aggression: Understanding, Identifying, and Responding in Schools. Psychology in the Schools, 43, 297-312. https://doi.org/10.1002/pits.20148

Zhu, Z., Nakata, C., \& Sivakumar, K. (2007). Self-Service Technology Effectiveness: The Role of Design Features and Individual Traits. Journal of the Academy of Marketing Science, 35, 492-506. https://doi.org/10.1007/s11747-007-0019-3 
Zhu, Z., Nakata, C., Sivakumar, K., \& Grewal, D. (2013). Fix It or Leave It ? Customer Recovery from Self-Service Technology Failures. Journal of Retailing, 89, 15-29.

https://doi.org/10.1016/j.jretai.2012.10.004 